NBER WORKING PAPER SERIES

\title{
AN INDEX OF GLOBAL ECONOMIC POLICY UNCERTAINTY
}

\author{
Steven J. Davis \\ Working Paper 22740 \\ http://www.nber.org/papers/w22740 \\ NATIONAL BUREAU OF ECONOMIC RESEARCH \\ 1050 Massachusetts Avenue \\ Cambridge, MA 02138 \\ October 2016
}

I thank Hanna Ni for excellent research assistance and the U.S. National Science Foundation for financial support. This paper builds directly on my research with Scott Baker and Nick Bloom and uses data from our website at www.PolicyUncertainty.com. The views expressed herein are those of the author and do not necessarily reflect the views of the National Bureau of Economic Research.

NBER working papers are circulated for discussion and comment purposes. They have not been peer-reviewed or been subject to the review by the NBER Board of Directors that accompanies official NBER publications.

(C) 2016 by Steven J. Davis. All rights reserved. Short sections of text, not to exceed two paragraphs, may be quoted without explicit permission provided that full credit, including (C) notice, is given to the source. 
An Index of Global Economic Policy Uncertainty

Steven J. Davis

NBER Working Paper No. 22740

October 2016

JEL No. D80,E66,G18,L50

\begin{abstract}
$\underline{\text { ABSTRACT }}$
Building on Baker, Bloom and Davis (2016), I construct a monthly index of Global Economic Policy Uncertainty (GEPU) from January 1997. The GEPU Index is a GDP-weighted average of national EPU indices for 16 countries that account for two-thirds of global output. Each national EPU index reflects the relative frequency of own-country newspaper articles that contain a trio of terms pertaining to the economy, uncertainty and policy-related matters. The GEPU Index rises sharply in reaction to the Asian Financial Crisis, the 9/11 terrorist attacks, the U.S.-led invasion of Iraq in 2003, the Global Financial Crisis in 2008-09, the European immigration crisis, concerns about the Chinese economy in late 2015, and the Brexit referendum in June 2016. It fluctuates around consistently high levels from mid 2011 to early 2013, a period characterized by recurring sovereign debt and banking crises in the Eurozone, intense partisan battles over fiscal and healthcare policies in the United States, and a generational leadership transition in China. The average value of the GEPU Index is 60 percent higher from July 2011 to August 2016 than in the previous fourteen and one-half years and 22 percent higher than in 2008-09.
\end{abstract}

Steven J. Davis

Booth School of Business

The University of Chicago

5807 South Woodlawn Avenue

Chicago, IL 60637

and NBER

Steven.Davis@ChicagoBooth.edu 
The first essential step in the direction of learning any subject is to find principles of numerical reckoning and practicable methods for measuring some quality connected with it.

Lord William Thompson Kelvin, 1883

\section{Introduction}

Democratic decision-making is often messy and fraught with uncertainty about outcomes and economic consequences. The 2016 U.S. election cycle illustrates this claim vividly, as does the United Kingdom's June 23 referendum in favor of leaving the European Union. Writing in September 2016, Financial Times columnist Wolfgang Münchau puts it this way: "Britain's vote to leave the EU has been the most cataclysmic global political event this year so far. Over the next 12 months, we may see one or more of the following: a victory of Donald Trump in the US; a defeat of Italy's government in a referendum over constitutional reforms; a Marine Le Pen victory in the French presidential election; a rightwing anti-immigration and anti-euro party becoming Germany's largest opposition party. Not all these calamities will happen. But one or two might."1

Beyond Western Europe and the United States, there are other notable examples of economic uncertainty emanating from political developments. In Brazil, a long and severe recession, an extraordinary wave of corruption investigations, and the recent impeachment and removal of its president have combined to upend the political landscape. Brazil's new president promises to restore growth by reversing several major policies of his predecessor. ${ }^{2}$ His success in this endeavor is highly uncertain. In Turkey, after squashing an attempted coup d'état in July, the government set about arresting and firing more than a hundred thousand teachers, military officers, judges, mayors, civil servants, and others. ${ }^{3}$ Ten weeks after the failed coup, Moody's Investor Service downgraded Turkey's sovereign credit rating - citing external funding risks, slowing growth and "further concerns regarding the predictability and effectiveness of

\footnotetext{
1 "Scare stories will not stop populist insurrections," Financial Times, 25 September 2016.

2 "Time for Temer: The new president takes over a country in crisis," The Economist, 3 September 2016.

3 “Turkey uses post-coup emergency decree to purge mayors and teachers," New York Times, 9 September 2016; and “Turks see purge as witch hunt of 'medieval' darkness,” New York Times, 16 September 2016.
} 
government policy and the rule of law." "4 The coup attempt and its aftermath have also strained international relations between Turkey and several of its allies. ${ }^{5}$

Autocratic regimes also produce economic uncertainty. Russia's annexation of Crimea in 2014 and its military incursions in eastern Ukraine led to international sanctions and an uncertain environment that curtailed foreign investment in Russia and contributed to its weak economic performance (European Parliament, 2016). The Russia-Ukraine conflict and its unsettled nature have harmed the Ukrainian economy as well and deterred foreign investment there (Morelli, 2016). China's aggressive pursuit of sovereignty claims in the South China Sea has raised concerns about threats to ship-borne trade in some of the world's busiest international waters. ${ }^{6}$ Syria has become the epicenter of a many-sided military conflict and humanitarian catastrophe, with highly uncertain long-term consequences. The Syrian conflict has produced a flood of migrants into neighboring countries and Europe, stoking security fears, creating anxiety about social and economic consequences, and placing enormous strains on the Schengen zone arrangements for free mobility in a border-less Europe. ${ }^{7}$

These recent examples, drawn from many parts of the world, suggest that governments and political processes are important sources of economic uncertainty. Policy-related uncertainty also arises as a consequence of major economic shocks and disruptions. As a leading example, the Global Financial Crisis of 2008-09 confronted policymakers with extraordinary and complex challenges. There was great uncertainty about how policymakers should and would respond to the challenges, and what would be the economic consequences.

Many theoretical analyses show how uncertainty potentially affects investment, hiring, consumption, financing costs, asset prices, output growth and other economic outcomes. Bernanke (1983) points out that high uncertainty gives firms an incentive to delay investment and hiring when investment projects are costly to undo or workers are costly to hire and fire. Once uncertainty recedes, firms increase hiring and investment to meet pent-up demand according to this theory. Other theories show how uncertainty can exert contractionary effects through upward pressure on the cost of finance (e.g., Gilchrist et al., 2014, and Pastor and

\footnotetext{
4 “Moody's cuts Turkey's credit rating to 'junk'," Reuters, 24 September 2016.

5 “The aftermath of Turkey's failed coup threatens its ties with Western allies," Washington Post, 21 September 2016.

6 "South China Sea ruling increases uncertainty for shipping, trade,” Wall Street Journal, 14 July 2016.

${ }^{7}$ See Baker et al. (2015a), Halla et al. (2015) and "Schengen: Controversial EU free movement deal explained," BBC News, 24 April 2016 at http://www.bbc.com/news/world-europe-13194723.
} 
Veronesi, 2013), precautionary spending cutbacks by households (e.g., Giavazzi and McMahon, 2012), underinvestment by risk-averse managers (e.g., Panousi and Papanikolaou, 2012), and the intensification of monopoly pricing distortions (Fernandez-Villaverde et al., 2015). Attention to the detrimental effects of policy uncertainty per se dates at least to Friedman (1968) and Rodrik (1991)..$^{8}$

In the spirit of Lord Kelvin's remark 133 years ago, Scott Baker, Nick Bloom and I have set out to measure policy-related economic uncertainty in countries around the world. We tap digital newspaper archives and other text sources to construct a wide range of economic policy uncertainty (EPU) indices. The aim of our newspaper-based measures is to capture uncertainty about who will make economic policy decisions, what economic policy actions will be undertaken and when, and the economic effects of policy actions (or inaction) - including uncertainties related to the economic ramifications of "non-economic" policy matters, e.g., military actions.

We see the effort to systematically measure policy uncertainty as an essential step toward addressing several important questions. For example, what role does policy uncertainty play in long-term economic performance and in cyclical fluctuations? Do severe contractions and major financial crises impart lasting negative effects on the economy by unsettling the political landscape and raising policy uncertainty? Can policy uncertainty measures sharpen our understanding of asset price behavior and help explain the volatility of national, industry and firm-level equity returns?

This paper builds on my work with Baker and Bloom to construct a Global Economic Policy Uncertainty (GEPU) Index. The GEPU Index is a GDP-weighted average of national EPU indices for 16 countries that account for two-thirds of global output. Each national EPU index reflects the relative frequency of own-country newspaper articles that contain a trio of terms pertaining to the economy, uncertainty and policy-related matters. As discussed below, the mean value of the GEPU Index is 60 percent greater from July 2011 to August 2016 than in the previous fourteen and one-half years and 22 percent greater than in the crisis years of 2008 and 2009.

\footnotetext{
${ }^{8}$ See Bloom (2014) for an overview of the literature on economic uncertainty and its effects, Baker et al. (2016) for a fuller list of references to research on policy uncertainty, and Baker et al. (2014) for references to related research in political science.
} 


\section{Using Newspapers to Quantify Economic Policy Uncertainty}

Baker et al. (2016) construct indices of economic policy uncertainty based on newspaper coverage frequency. Their modern monthly EPU index for the United States relies on 10 major newspapers. Specifically, they search the digital archives of each paper to obtain a monthly count of articles that contain the following trio of terms: "uncertainty" or "uncertain"; "economic" or "economy"; and one or more of the following policy terms: "congress," "deficit," "Federal Reserve," "legislation," "regulation" or "White House" (including variants like "uncertainties," "regulatory" and "the Fed"). In other words, to meet their EPU criteria, an article must contain terms in all three categories pertaining to the economy $(\mathrm{E})$, policy $(\mathrm{P})$ and uncertainty $(\mathrm{U})$. They scale the raw count by the total number of articles in the same newspaper and month. For each paper, they then standardize the monthly series of scaled counts to unit standard deviation over time. The final step averages the standardized, scaled counts across the ten papers by month to obtain the monthly EPU index. Thus we can think of the monthly EPU index value as proportional to the average share of newspaper articles that discuss economic policy uncertainty in that month.

A basic question raised by this approach is how to choose the specific terms that determine whether the computer-automated reading classifies an article as "EPU=Yes" or "EPU=No." Concerns related to this choice are most acute for the $\mathrm{P}$ term set, because many policy-related terms are potentially helpful in flagging articles about economic policy uncertainty. For any given term set, a computer-automated classification is subject to two types of errors: False positives, whereby the computer classifies an article as "EPU=Yes" but a careful human reading of the same article concludes "EPU=No." And false negatives, whereby the computer classifies an article as "EPU=No" but a careful human reading concludes "EPU=Yes." The optimal P term set is far from obvious.

To address this issue, we conducted a large-scale human audit of 12,000 articles drawn randomly from U.S. newspapers. Working under our close supervision, teams of University of Chicago students underwent a training process and then carefully read overlapping subsets of the 12,000 articles, guided by a 65-page reference manual and weekly team meetings. The auditors coded each article as "EPU=Yes" or "EPU=No" in light of the economic policy uncertainty 
concept we sought to identify, as described above in the Introduction. ${ }^{9}$ We then compared these human classifications to the computer-automated classifications implied by tens of thousands of possible $\mathrm{P}$ term sets. For each $\mathrm{P}$ term set, the computer-automated classification determines a set of false positives and false negatives relative to the human classification. We chose as our preferred $\mathrm{P}$ term set the one that minimizes the sum of false positives and false negatives.

Our approach to measuring policy uncertainty also raises potential concerns related to newspaper reliability, accuracy, bias, and consistency. We undertook several investigations to assess these concerns. First, we created a separate newspaper-based index of equity market uncertainty. Specifically, we used the same newspapers, scaling methods and search criteria except for dropping the P term set and, instead, requiring an article to contain "stock price," "equity price" or "stock market." The resulting index is highly correlated with the VIX, a market-based measure of uncertainty implied by traded equity options. This result demonstrates that frequency counts of suitably selected newspaper articles yield a reasonable proxy for an important type of economic uncertainty - a proof-of-concept for our basic approach.

Second, we find a strong relationship between our newspaper-based EPU Index and other text-based measures of policy uncertainty, e.g., the frequency with which the Federal Reserve System's Beige Books mention policy uncertainty. Third, we find very similar movements in EPU indices based on right-leaning and left-leaning newspapers, suggesting that political slant does not seriously distort our overall EPU index. Fourth, following Baker, Bloom and Davis (2015b), we show that periods characterized by high (low) levels of policy uncertainty according to our newspaper-based EPU index also exhibit a high (low) frequency of large daily stock market moves triggered by news about government policy. Finally, our EPU indices have a market-use validation: Major data providers like Bloomberg, FRED, Haver and Reuters carry our indices to meet demands from banks, hedge funds, corporations and policy makers. This pattern of market adoption suggests that our indices contain useful information for a range of decision makers.

\footnotetext{
${ }^{9}$ For more information on the audit process, see Baker et al. (2016) and the Audit Guide at http://www.policyuncertainty.com/media/Coding_Guide.pdf.
} 


\section{An Index of Global Economic Policy Uncertainty}

Using similar methods, Baker, Bloom and I also construct monthly newspaper-based EPU indices for thirteen other countries: Australia, Brazil, Canada, China, France, Germany, India, Italy, Japan, Russia, South Korea, Spain, and the United Kingdom. We perform all searches in the native language of the newspaper. To help develop suitable E, P and U term sets, we consulted persons with native fluency and economics expertise in the relevant language and country. Our P term set differs across countries for reasons both obvious (e.g., using "BOJ" for Japan) and idiosyncratic (e.g., inclusion of "customs duties" for India). Kroes et al. (2015) and Zala (2016) follow our methods to construct EPU indices for the Netherlands and Ireland, respectively. Monthly data for all 16 national EPU indices are available and regularly updated at www.PolicyUncertainty.com. The data extend back to 1997 or earlier except for Australia (1998), India (2003), the Netherlands (2003), and Spain (2001).

To construct a Global Economic Policy Uncertainty (GEPU) Index, I proceed as follows: First, I re-normalize each national EPU index to a mean of 100 from 1997 (or first year) to 2015. Second, I impute missing values for Australia, India, the Netherlands and Spain using a regression-based method. ${ }^{10}$ This step yields a balanced panel of monthly EPU index values for 16 countries from January 1997 to August 2016. Third, I compute the GEPU Index value for each month as the GDP-weighted average of the 16 national EPU index values, using GDP data from the IMF's World Economic Outlook Database.

Figure 1 plots two versions of the resulting GEPU Index - one based on current-price GDP measures, and one based on PPP-adjusted GDP. The 16 countries that enter into the GEPU Index account for two-thirds of global output on a PPP-adjusted basis and roughly three-quarters of global output at current prices. I will refer to the PPP-adjusted version in remarks below, but the two versions are extremely similar.

The GEPU Index rises sharply in reaction to the Asian and Russian Financial Crises, the 9/11 terrorist attacks, the U.S.-led invasion of Iraq in 2003, the Global Financial Crisis in 200809, the European immigration crisis and concerns about the Chinese economy in late 2015, and

\footnotetext{
${ }^{10}$ For example, I regress the EPU index for Australia from 1998 onwards on contemporaneous EPU index values for all countries with no missing data. I then use predicted values from this regression to impute the missing Australian values for 1997 .
} 
the Brexit referendum in June 2016. ${ }^{11}$ It fluctuates around consistently high levels from mid 2011 to early 2013, a period characterized by recurring sovereign debt and banking crises in the Eurozone, intense battles over fiscal and healthcare policies in the United States, and a generational leadership transition in China. Seven of nine members on the Standing Committee, China's most powerful decision-making body, were slated for retirement in 2012. Other senior leadership bodies in China experienced similarly high turnover rates due to retirement, leading Li (2011) to characterize 2012 as the fourth "generational transfer of power" in the history of Communist China. Two of the previous transitions brought tragedy and turmoil in the form of the Cultural Revolution and the 1989 Tiananmen Square protests and massacre.

Eurozone developments in the period from mid 2011 to early 2013 include a rescue package for Portugal in May 2011, a bailout package for Greece in July 2011 (amidst widespread speculation that Greece would leave the Eurozone), large yield increases on Spanish and Italian government bonds in August 2011, April 2012 and June 2012, a May 2012 election in which most Greek voters rejected a proposed bailout agreement, and multiple extraordinary actions by the European Central Bank in response to these and other developments. Across the Atlantic, bitterly partisan disputes over the direction of U.S. fiscal policy led to a "debt-ceiling" fight in summer 2011 that threatened to curtail critical government functions and delay payments on U.S. Treasury securities, and an extraordinary "fiscal cliff” episode with last-minute resolutions of major uncertainties about tax and spending policies. Uncertainties surrounding U.S. healthcare policy were also extraordinarily high in this period. For example, an appellate struck down the Affordable Care Act (“Obamacare”) in August 2011, concluding that Congress lacked the constitutional authority to require individuals to purchase health insurance or pay a penalty, and threatening the viability of the entire Act. ${ }^{12}$ The issue remained unsettled until June 2012, when the Supreme Court reversed the appellate court in a surprise, closely divided decision. ${ }^{13}$

The mean value of the GEPU Index is 60 percent greater from July 2011 to August 2016 than in the previous fourteen and one-half years. Perhaps even more striking, the mean GEPU Index value since July 2011 is 22 percent greater than in 2008-2009, when policymakers

\footnotetext{
${ }^{11}$ Brazil also experienced extremely elevated policy uncertainty levels in late 2015 for largely domestic reasons tied to corruption scandals, indictments of major political figures and ultimately successful efforts to remove President Dilma Rousseff from office. These extraordinary developments in Brazil also pushed up the Global EPU Index in late 2015, but they appeared to have limited spillover effects on the rest of the global economy. Brazil's GDP weight in the Global EPU Index is about four percent.

${ }^{12}$ See "Health Law Is Dealt Blow by a Court on Mandate," New York Times, 12 August 2011.

${ }^{13}$ See "Court Backs Obama on Health Law," Wall Street Journal, 29 June 2012.
} 
confronted the worst global financial crisis since the 1930s. These findings indicate that policyrelated concerns have become a larger source of economic uncertainty in recent years.

\section{Concluding Remarks}

The elevated levels of global policy uncertainty in the past five years compared even to the crisis years of 2008-09 is remarkable. They have contributed to the disappointing performance of the global economy in recent years. By how much is an open question and an active area of research.

The findings in my research program with Baker and Bloom also raise other important questions. For example, why have many of the world's major economies experienced heightened levels of policy uncertainty in recent years? How can we craft institutional arrangements and policy frameworks that foster sound and predictable policy - even, and especially, in the face of large negative shocks? I hope the Global Economic Policy Uncertainty Index and the wide range of other EPU indices available at www.PolicyUncertainty.com will help answer these questions and the ones posed in the Introduction. 


\section{References}

Baker, Scott, Nicholas Bloom, Brandice Canes-Wrone, Steven J. Davis and Jonathan Rodden, 2014. "Why Has US Policy Uncertainty Risen Since 1960?" American Economic Review, Papers \& Proceedings, 104, no. 5, 56-60.

Baker, Scott, Nicholas Bloom and Steven J. Davis, 2015(a). "Immigration Fears and Policy Uncertainty," VoxEU, 15 December.

Baker, Scott, Nicholas Bloom and Steve J. Davis, 2015(b). "What triggers stock market jumps?" Work in progress presented at the January 2015 ASSA meetings.

Baker, Scott, Nicholas Bloom and Steven J. Davis, 2016. "Measuring Economic Policy Uncertainty," Quarterly Journal of Economics, doi:10.1093/qje/qjw024.

Bernanke, Ben S., 1993. "Irreversibility, Uncertainty and Cyclical Investment," Quarterly Journal of Economics, 97, no. 1, 85-106.

Bloom, Nicholas, 2014. "Fluctuations in Uncertainty," Journal of Economic Perspectives, 28, no. $2,153-176$.

European Parliament, 2016. "Briefing - Sanctions over Ukraine: Impact on Russia," March, at http://www.europarl.europa.eu/EPRS/EPRS-Briefing-579084-Sanctions-over-Ukraineimpact-Russia-FINAL.pdf

Fernandez-Villaverde, Jesus, Pablo Guerron-Quintana, Keith Kuester, and Juan Rubio-Ramirez, 2015. "Fiscal volatility shocks and economic activity," American Economic Review, 105, no. $11,3352-3384$.

Friedman, Milton, 1968 “The Role of Monetary Policy,” American Economic Review, 58, no. 1, 1-17.

Giavazzi, Francesco and Michael McMahon, 2012. "Policy Uncertainty and Household Savings," Review of Economics \& Statistics, 94, no. 2, 517-531.

Gilchrist, Simon, Jae W. Sim and Egon Zakrajsek, 2014. "Uncertainty, Financial Frictions, and Investment Dynamics,” NBER Working Paper 20038.

Halla, Martin, Alexander Wagner and Josef Zweimüller, 2015. "Immigration and Far-Right Voting: New Evidence," VoxEU, 29 November.

Kroese, Lars, Suzanne Kok and Jante Parlevliet, 2015. "Beleidsonzekerheid in Nederland," Economisch Statistiche Berichten, 4715: 464-467 (August). 
Li, Cheng, 2011. "The 2012 Chinese Leadership Transition," 11 December, https://www.brookings.edu/on-the-record/the-2012-chinese-leadership-transition/.

Morelli, Vincent L., 2016. "Ukraine: Current Issues and U.S. Policy," Congressional Research Service, 3 August.

Panousi, Vasia and Dimitris Papanikolaou, 2012. "Investment, idiosyncratic risk and ownership," Journal of Finance, 67, no. 3, 1113-1148.

Pastor, Lubos and Veronesi, Pietro, 2013. "Political Uncertainty and Risk Premia," Journal of Financial Economics, 110, no. 3, 520-545.

Rodrik, Dani, 1991. "Policy Uncertainty and Private Investment," Journal of Development Economics, 36, no. 2, 229-242.

Zalla, Ryan, 2016. "Economic Policy Uncertainty in Ireland," 20 September, http://www.policyuncertainty.com/media/Zalla_EPU_Ireland.pdf. 
